\title{
Adaptation of the red fox (Vulpes vulpes) body weight and thickness of the limbs to snow conditions in Scandinavia
}

\begin{abstract}
Jan K. Å. Englund
ABSTRACT. Intraspecific variation in body weight is a common phenomenon in many mammals and is largely related to variation in quality and abundance of foods. The amount of food in the spring-summer period may affect the growth of the young animals and in winter time affect the fat reserves both affecting the body weight. In this study I examined the winter body weight in adult red foxes Vulpes vulpes in five areas in Scandinavia. The amount of food varied strongly between years in the three northern areas. The winter body weight also varied between years, but this was not a result of that foxes in years with plenty of food were fatter. The reason was differences between years in the proportion of foxes born in years with varying amount of voles. Foxes in the north down to the central part of Sweden are of the same size at least the phenotypes. In spite of that foxes are heavier southwards. The reason is that foxes in the north have thinner bones, probably an adaptation to the amount of snow. In Scania in the most southern part of Sweden the foxes are the largest in Scandinavia and therefore the heaviest. Danish foxes are not as heavy as foxes in Scania. When studying the weights of wild animals in areas where food sometimes is extremely scarce, such as near the limits of the species range, it is important to treat data from different birth cohorts separately. To ignore that may result in misleading conclusions.
\end{abstract}

How to cite this article: Englund J.K.A. 2020. Adaptation of the red fox (Vulpes vulpes) body weight and thickness of the limbs to snow conditions in Scandinavia // Russian J. Theriol. Vol.19. No.1. P.71-78. doi: 10.15298/rusjtheriol.19.1.07.

KEY WORDS: anatomical adaptation, body weight, limb thickness, red fox, Scandinavia, snow conditions, Vulpes vulpes.

\section{Адаптивные изменения веса тела и строения конечностей лисиц (Vulpes vulpes) в зависимости от толщины снежного покрова в Скандинавии}

\begin{abstract}
Я.К.О. Энглунд
РЕЗЮМЕ. Внутривидовая изменчивость веса тела обычна для многих млекопитающих и зависит в большой степени от качества и обилия корма. Количество корма влияет в весенне-летний период на рост молодых, а в зимний период - на количество у них жировых отложений, что в итоге оказывает влияние на общий вес тела зверей. В статье проведен анализ изменчивости веса тела обыкновенной лисицы Vulpes vulpes в зимний период на пяти обширных территориях Скандинавии. В трех северных областях количество корма сильно варьирует по годам. Вес лисиц зимой также подвержен значительным колебаниям от года к году, но не в результате того, что лисицы в годы обилия пищи более упитанны. Причина кроется в том, что между годами наблюдаются различия в процентном соотношении лисиц, рожденных в годы разной численности полевок. Лисицы, населяющие территории от крайнего севера до центральной части Швеции, одного размера, по крайней мере, фенотипически. Несмотря на это, вес их увеличивается по направлению к югу. Как показывает анализ, кости конечностей лисиц северных областей более тонкие, что можно объяснить адаптацией к снежным условиям. В Сконии, самой южной территории Швеции, лисицы самые крупные в Скандинавии и, как следствие, самые тяжелые. Датские лисицы уступают сконским в весе. При изучении веса тела диких животных, населяющих территории, где кормовая база подвержена значительным колебаниям, как, например, на границе ареалов, необходимо анализировать данные отдельно по годам рождения. В противном случае можно прийти к ошибочным заключениям.
\end{abstract}

КЛЮЧЕВЫЕ СЛОВА: анатомические адаптации, вес тела, толщина конечностей, рыжая лиса, Скандинавия, снежный покров, Vulpes vulpes. 


\section{Introduction}

Intraspecific variation in body weight is a common phenomenon in many mammals and is largely related to spatial variation in quality and abundance of foods. The amount of food in the spring-summer period may affect the growth of the young animals and in winter time it may affect the fat reserves, both affecting the body weight. The objective of this study was to examine the winter body weight as well as the thickness of the limbs in red foxes (Vulpes vulpes L., 1758) in five areas in Scandinavia focusing on the regional ecological factors influence on these variables.

\section{Material and methods}

The present paper is based on data from foxes collected for ecological work at the Swedish Museum of Natural History in Stockholm during the years of 1966 through 1986 (Englund, 1970, 1980) and additional data from foxes collected in 2010-2018.

Some foxes are from the coniferous belt in northern and others from the coniferous belt in southern Norrland (here called S1, 62-68 $\mathrm{N}$, and S2, 59.5-62 ${ }^{\circ} \mathrm{N}$ ). The agricultural habitats are represented by three areas, the central part of Sweden $\left(\mathrm{S} 3,58.5-60^{\circ} \mathrm{N}\right)$ and the most southern province in Sweden called Scania (S4, $\left.55.3-56.3^{\circ} \mathrm{N}\right)$ and Denmark (Dk, 55-58 $\mathrm{N}$, Fig. 1).

During the years of 1950-1980 the ground in northern Norrland (S1) was covered with snow about 150 to 225 days per year, and the mean depth in February, 15 was $400-800 \mathrm{~mm}$. The corresponding figures for southern Norrland (S2) were 100-150 days with 300-500 mm snow, for central Sweden between 75-125 days and 100$300 \mathrm{~mm}$ and for Scania up to 75 days with 100-200 mm of snow (Eriksson, 1989).

The productivity in the two northern areas (S1 and $\mathrm{S} 2$ ) is low, especially in S1, while S3 is much more productive. The main preys in all three areas are voles, mostly Microtus agrestis and Arvicola amphibius, which fluctuate heavily in numbers between years.

The amount of food varied strongly within the three northern areas depending on the yearly variation in the numbers of voles. The estimates are based on analyses of stomach contents (Englund, 1970, 1980).

In December 1967-April 1968 the mean number of voles per stomach in S1 was 0.1 (which is extremely low). In the winter $1968-1969$ it was 0.5 to 0.6 , and in 1969-1970 it was 1.6 to 0.8 voles per stomach. In $1967-1968$ it was 0.3 to 0.1 voles per stomach in S2, and in the winter 1968-1969 the corresponding figures was 0.6 and 0.4. In the summer of 1969 the number of voles increased. In the winter 1967-1968 it was 0.4 to 0.5 voles per stomach in S3, which increased to 1.4 in December 1968 and was 0.7 in January-April 1969. In the winter $1969-1970$ it was 0.6 to 0.5 voles per stomach.

Scania in the most southern part of Sweden is a very high productive area with plenty of food and with a low variation between years. Apart from voles there were plenty of rabbits (Oryctolagus cuniculus) and hares (Lepus europaeus) in Scania. In 166 stomachs with contents there were remnants of 138 small rodents and 79 members of the family Leporidae $(48 \%$, out of which 9 specimens were hares and 21 were rabbits (Englund, 1965). Furthermore, there were large game birds, mostly pheasants (Phasianus colchicus), in $18 \%$ of the stomachs. According to von Schantz (1980) 78 to $89 \%$ of the weight of the fox food constitutes of hares and rabbits. Thus large prey constitutes a considerable part in their diet, which is quite different from the rest of Sweden (Englund, 1965, 1970). The main preys in Denmark are voles and hares (Jensen \& Sequeira, 1978; Pagh et al., 2015).

Juveniles were distinguished from older foxes by the open sutures in the long bones or by the presence of an open suture between the basioccipital and basisphenoid bones in the cranium (Churcher, 1960). Other foxes were aged by the incremental annuli in the tooth cementer of the canines.

Body weight is given in $\mathrm{kg}$ from adult foxes shot in December, 1 - March, 31 (in S1 until April, 30). Nearly all foxes have been weight by the hunters to the nearest $0.1 \mathrm{~kg}$.

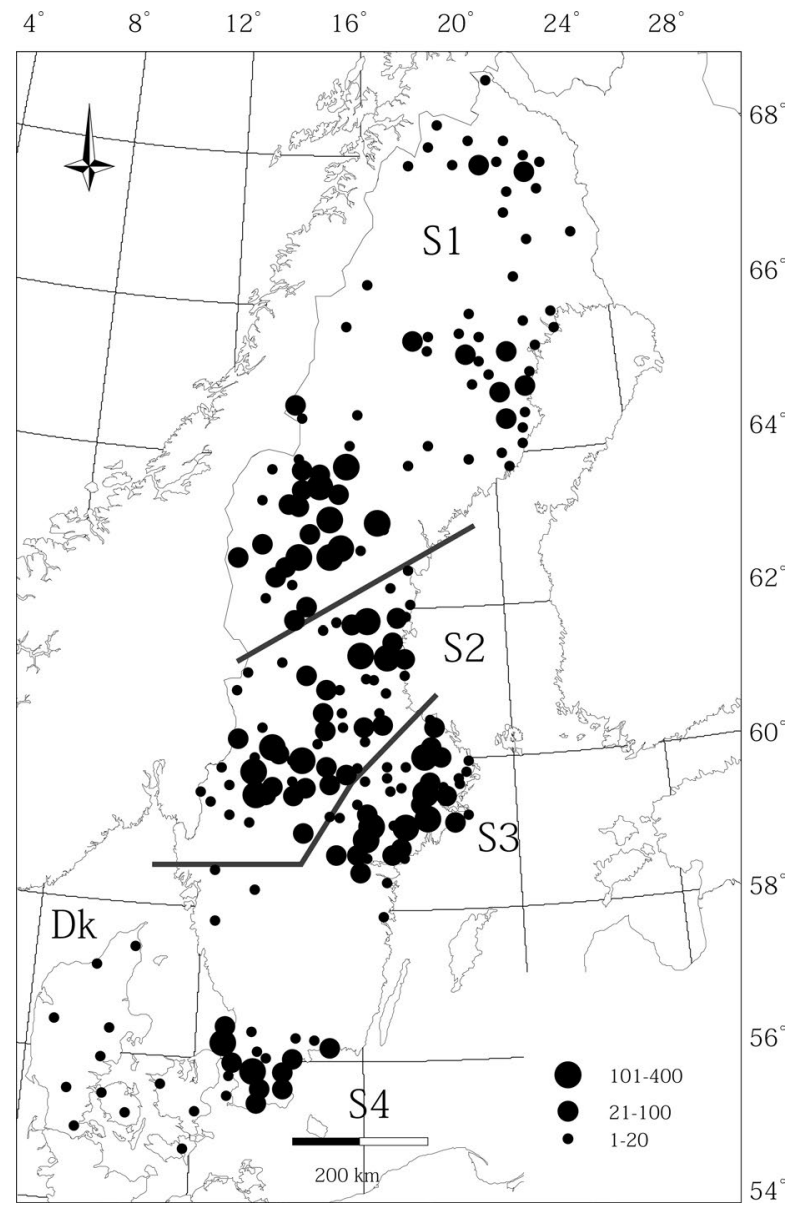

Fig. 1. The distribution of the material per $50 \times 50 \mathrm{~km}$ squares within five areas in Scandinavia (S1 - northern Norrland, S2 - southern Norrland, S3 - central Sweden, S4 - Scania, Dk - Denmark). Size of black circles show the number of studied fox specimens. 
The thickness of the long bones has been measured to the nearest $0.1 \mathrm{~mm}$ at the thinnest place and in 90 degrees relative to the movement direction as described by von den Driesch (1976). When calculating the mean diameter of the long bones only data from foxes, where the long bones are supposed to be full grown according to the sutures, are used. Thus yearlings are included.

To examine whether foxes in different groups differed in weight, ANOVA-tests followed by Hochberg's GT2 post hoc tests were carried out. Differences in measurements are considered significant when $p<$ 0.02 . Figures were drawn using the software package PIA (Bignert, 2013). The error bars specify the $95 \%$ confidence interval of the mean.

\section{Results}

\section{Weight}

The mean weight of adult males and females in northern Norrland was 6.5 and $5.4 \mathrm{~kg}$ in winter time. Southward the weight increased up to 8.8 and 7.0 in Scania (S4). In Denmark, at the same latitude as Scania, the mean weight was 7.3 and $5.8 \mathrm{~kg}(p<0.001$, Fig. 2, Appendix 1).

The foxes in northern Norrland were heaviest in the winter 1967/1968, the winter when the voles were extremely few (Englund, 1970, 1980). When the voles

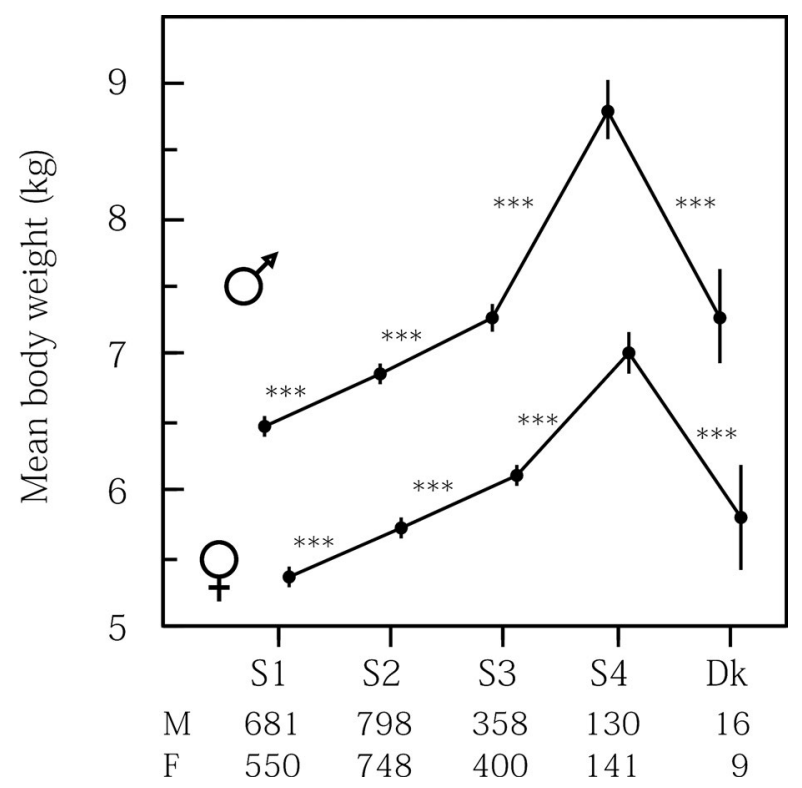

Fig. 2. Mean winter body weight in adult red foxes (all birth cohorts shot in 1966 through 2018 are lumped together). The error bars specify the $95 \%$ confidence interval of the mean $(* * *-p<0.001) . \mathrm{M}$ - the number of males and $\mathrm{F}$ - the number of females. increased in numbers in the summer of 1968, the number of voles per stomach increased from 0.1 to 0.5 in the winter of $1968 / 1969$, which is rather good. The body weight among foxes decreased that winter with six per cent in males and with nine per cent in females (Fig. 3; $p<0.01)$. In the winter of $1969 / 1970$ the voles were very common (1.4 per stomach) but this had no effect on the mean body weight in the foxes.

In southern Norrland and central Sweden, however, the mean body weight was not significantly different in the two winters of 1967/1968 and 1968/1969 in spite of large differences in the amount of voles ( $p>0.02$; depending on the very few specimens from the third winter these are omitted from the tests of significance).

The mean weight in foxes, born in 1966 in northern Norrland, was about the same all three winters 1967/1968 through 1969/1970 in spite of great differences in the amount of food. And also the foxes born in $1967 \mathrm{had}$ about the same body weight $1968 / 1969$ and 1969/1970 $(p>0.05$, Table 1$)$.

The mean weight in adult foxes born 1966, when the voles were extremely abundant in all the three northern areas (S1-S3), and killed during the coming years, was highest in the central part of Sweden (Table 2, $p<0.001$ ), while the weight of the foxes in the two northern areas did not differ $(p>0.05)$.

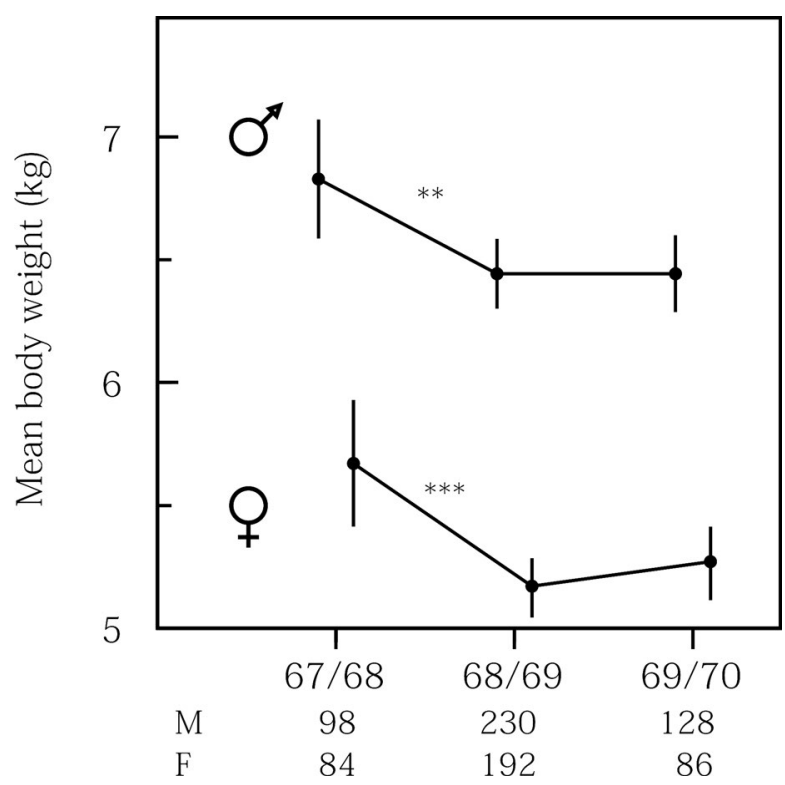

Fig. 3. Mean winter body weight during three consecutive winters in adult foxes from northern Norrland (all birth cohorts are lumped together). The error bars specify the $95 \%$ confidence interval of the mean $(* *-p<0.01$ and $* * *-p<0.001)$. $\mathrm{M}$ - the number of males and $\mathrm{F}$ - the number of females. There were $0.1-0.2$ voles per stomach in the winter 1967/1968, $0.5-0.6$ in $1968 / 1969$ and $1.6-0.8$ in $1969 / 1970$. 
Table 1. Mean number of voles per stomach, number of specimens $(n)$ and mean body weight $(\mathrm{kg})$ during three winters in adult Vulpes vulpes born 1966 and 1967 in northern Norrland (S1).

\begin{tabular}{|c|c|c|c|c|c|c|}
\hline Winters & $1967 / 68$ & $n$ & $1968 / 69$ & $n$ & $1969 / 70$ & $n$ \\
\hline voles/stomach & 0.1 & 116 & 0.5 & 179 & 1.4 & 99 \\
\hline males (1966) & 6.8 & 59 & 6.8 & 86 & 6.9 & 49 \\
\hline females (1966) & 5.7 & 46 & 5.2 & 74 & 5.4 & 32 \\
\hline males (1967) & & & 6.1 & 96 & 6.2 & 29 \\
\hline females (1967) & & & 5.0 & 68 & 5.1 & 25 \\
\hline
\end{tabular}

Table 2. Mean body weight ( $\mathrm{kg})$ in adult Vulpes vulpes born 1966 and killed in the three northern areas during the winters 1967-1968.

\begin{tabular}{|c|c|c|c|c|c|c|}
\hline Sex & \multicolumn{3}{|c|}{ Males } & \multicolumn{3}{|c|}{ Females } \\
\hline Region & S1 & S2 & S3 & S1 & S2 & S3 \\
\hline Mean & 6.8 & 6.7 & 7.4 & 5.4 & 5.5 & 6.1 \\
\hline sd & 1.09 & 1.09 & 1.04 & 1.03 & 0.74 & 0.92 \\
\hline$n$ & 205 & 73 & 66 & 168 & 71 & 72 \\
\hline
\end{tabular}

\section{Long bones}

The long bones are thinnest in northern Norrland, and thicker southwards down to Scania. The bones in Denmark, however, are as thin as in foxes from the central part of Sweden (Fig. 4, Table 3 and Appendix 2; the diagrams of the other long bones look the same as for femur).

Foxes born 1966 in northern Norrland, when the voles were extremely common, got thicker bones than foxes born 1967, when the voles were extremely rare ( 0.1 vole per stomach). The difference varied between 2 and $5 \%$ with $p<0.01$ in all comparisons (Table 4, Appendix 3).

Four times out of four, foxes born 1966 in S2 and S3 got thicker humerus than foxes born 1967 ( $p<0.01$ in two of the comparisons with a difference of $2 \%$; Table 4). In twelve times out of twelve the other long bones in foxes born 1966 were thicker than in foxes born 1967, but the differences were small and not significant in any of the comparisons (Appendix 3).

The thickness of the long bones in foxes born 1966 in S1 and S2, the year the voles were extremely common, did not differ significantly (Table 5, Appendix 3). The foxes born 1966 in central Sweden as well as foxes from Scania (S4; all birth cohorts lumped together) on the other hand had thicker bones than foxes born 1966 in S1 and S2 (Table 3, 5 and Appendix 2, 3). Compared with northern

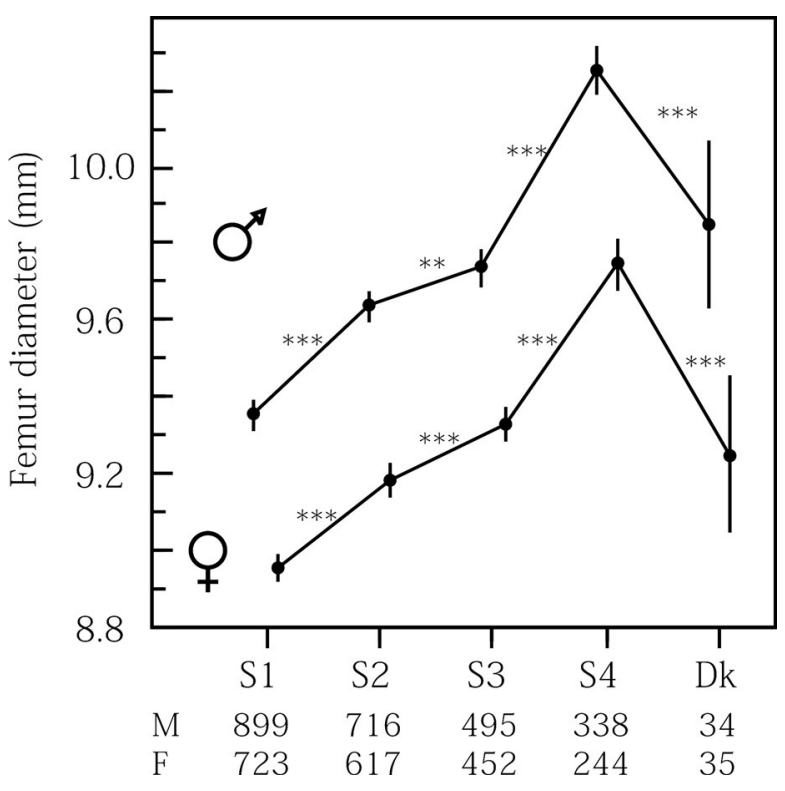

Fig. 4. Mean diameter of femur (all birth cohorts are lumped together). The error bars specify the $95 \%$ confidence interval of the mean $(* *-p<0.01$ and $* * *-p<0.001)$. $\mathrm{M}-$ the number of males and $\mathrm{F}$ - the number of females.

Table 3. The mean (mm) of the thinnest breadth (all birth cohorts are lumped together) in Vulpes vulpes.

\begin{tabular}{|c|c|c|c|c|c|c|c|c|c|c|}
\hline Sex & \multicolumn{5}{|c|}{ Males } & \multicolumn{5}{c|}{ Females } \\
\hline Region & S1 & S2 & S3 & S4 & Dk & S1 & S2 & S3 & S4 & Dk \\
\hline Humerus & 8.21 & 8.51 & 8.65 & 9.07 & 8.64 & 7.82 & 8.03 & 8.20 & 8.55 & 8.07 \\
\hline Radius & 8.35 & 8.57 & 8.68 & 9.27 & 8.49 & 7.85 & 8.03 & 8.15 & 8.67 & 7.96 \\
\hline Femur & 9.35 & 9.64 & 9.74 & 10.25 & 9.85 & 8.95 & 9.18 & 9.33 & 9.75 & 9.25 \\
\hline Tibia & 8.22 & 8.46 & 8.63 & 9.22 & 8.65 & 7.81 & 8.02 & 8.17 & 8.73 & 8.18 \\
\hline
\end{tabular}


Table 4. The differences (in $\mathrm{mm}$ ) of the thinnest breadth of the long bones in Vulpes vulpes born 1966 compared with these born 1967. (**) $-p<0.01$ and $(* * *)-p<0.001$.

\begin{tabular}{|c|c|c|c|c|}
\hline & Humerus & Radius & Femur & Tibia \\
\hline S1 males & $0.43 * * *$ & $0.34 * * *$ & $0.37 * * *$ & $0.17 * *$ \\
\hline S1 females & $0.31 * * *$ & $0.21 * * *$ & $0.34 * * *$ & $0.26 * * *$ \\
\hline S2 males & 0.10 & 0.08 & 0.05 & 0.11 \\
\hline S2 females & 0.14 & 0.06 & 0.03 & 0.07 \\
\hline S3 males & $0.18 * *$ & 0.09 & 0.02 & 0.11 \\
\hline S3 females & $0.16 * *$ & 0.09 & 0.10 & 0.18 \\
\hline
\end{tabular}

Table 5. The mean (mm) of the thinnest breadth of the long bones in Vulpes vulpes born 1966, when the voles were extremely abundant in all the three northern areas.

\begin{tabular}{|c|c|c|c|c|c|c|}
\hline Sex & \multicolumn{3}{|c|}{ Males } & \multicolumn{3}{c|}{ Females } \\
\hline Region & S1 & S2 & S3 & S1 & S2 & S3 \\
\hline Humerus & 8.43 & 8.52 & 8.76 & 7.96 & 8.00 & 8.27 \\
\hline Radius & 8.53 & 8.55 & 8.72 & 7.94 & 7.97 & 8.19 \\
\hline Femur & 9.57 & 9.59 & 9.78 & 9.17 & 9.11 & 9.36 \\
\hline Tibia & 8.33 & 8.40 & 8.69 & 7.97 & 7.95 & 8.23 \\
\hline
\end{tabular}

Norrland the foxes from central Sweden had thicker bones eight times out of eight (seven times with $p<0.01$; all birth cohorts lumped together). And the thickness of the bones in the Danish foxes was about the same as in the foxes from the central part of Sweden (Fig. 4).

Thus the bones are thicker southwards.

\section{Discussion}

1). The body weight in foxes increases from the most northern part of Sweden to the most southern part. Why? Are the southern foxes fatter since they inhabit more productive areas or are they larger as an adaptation to local challenges?

Before discussing these questions the effect of vole population fluctuations in foxes in northern Norrland (S1) has to be clarified.

Cubs born in northern Norrland those years when the voles are very common will grow larger, than foxes born when the voles are few (Englund, 2006, 2019). Furthermore the proportion of adult foxes from different birth cohorts varies strongly from year to year, since the productivity of cubs and their survival varies between years (Englund, 1970, 1980). As a result of that, the proportion of large foxes born in years with plenty of voles, and small foxes born in years with very few voles, varies from year to year. To find out what effect the amount of voles during the autumn-winter period will have on the winter body weight of the foxes, it is therefore necessary to select separate birth cohorts and compare their weights during winters with varying amount of voles. (Neglecting these facts, when using material from areas with large variation in the amount of food, may easily lead to a false conclusion about the effect of the variation in the number of voles on the winter body weight in adult foxes. In the present material for example a high proportion of the foxes killed in the winter 1967-1968, when the voles were extremely few, were born in 1966 when the voles were very common, and thus many of the foxes killed that winter were very large and heavy. Therefore males and females were six and nine per cent heavier the winter, when the voles were extremely scarce, indicating that foxes will be very fat and heavy when they are starving (Fig. 3, $p<0.01$ ), which is a rather absurd conclusion).

2 ). The mean size of the foxes in the three northern areas in Sweden (S1 to S3) is about the same (all birth cohorts lumped together; unpublished data). In spite of that the mean weight differ, increasing from north to south ( $p<0.001$, Fig. 2, Appendix 1). May these differences depend on that foxes are fatter in the south? Unfortunately there is no information about how fat the foxes were. But how much will the winter body weight vary depending on the varying amount of voles during different winters?

The number of foxes, which were born in 1966 and 1967 in northern Norrland (S1) and shot as adults in winter time, is sufficient for a meaningful comparison. In spite of a large variation in the number of voles during the different years, the mean body weight was about the same all the winters (Table 1). Thus there is no reason to believe that the foxes were fatter in years with plenty of food than the foxes were in years with few voles.

3). The foxes collected in southern Norrland (all birth cohorts lumped together) were heavier than the foxes in northern Norrland (Fig. 2). The reason for that is not that the foxes in southern Norrland were fatter. The reason is the effect of the extreme scarcity of voles in northern Norrland in the summers of 1967 and 1968 resulting in small foxes with a low body weight (Englund, 2019). The mean weight of foxes born in 1966 in these two regions, as well as the diameter of their bones was about the same, since the amount of voles was extremely good in both northern and southern Norrland this year (Table 2, 5). 
4). Since the very large differences in the amount of food in the three winters of 1967/1968 up to and including $1969 / 1970$ in northern Norrland had no effect on the body weight (Table 1), there is no reason to believe that the foxes in central Sweden (S3) were fatter because the food situation there was better than in northern and southern Norrland (S1, S2). So why were the foxes in central Sweden 0.6 to $0.7 \mathrm{~kg}$ heavier than the foxes in the two northern areas ( 9 to $13 \%, p<0.001$, Table 2$)$ ?

Since the long bones are thicker in the south (Fig. 4 , Table 3,5), indicating that all skeleton parts may be thicker, I believe this is the reason why the foxes in central Sweden are heavier than the foxes further north.

$5)$. But why are the bones thinner northwards? Is it caused by lack of food and calcium? Since voles were extremely abundant in all the three northern areas in the spring and summer 1966, pups born this year can hardly have suffered from lack of calories or calcium in any of the three areas. And in spite of that, the long bones in foxes from the central part of Sweden were thicker than among the foxes in the two northern areas (Table 5, Appendix 3). A reasonable explanation of the data therefore will be that foxes with thin bones in the north have been favoured by the evolution.

In the middle of the winter the mean depth of snow in northern Norrland (S1) is about $400-800 \mathrm{~mm}$ and in southern Norrland (S2) around 300-500 mm, while there is no more than 100-300 mm of snow in the central part of Sweden (Eriksson, 1989). Furthermore the winters are much longer in the north than in the south. A possible reason for the thin bones in the north therefore might be that light foxes will not sink so deep into the snow as heavy foxes, and thus they will save energy when moving in the north. Another possibility is that with a reduced body weight, the proportion of the length of femur, tibia and the hind foot can change, making the foxes to be better jumpers, a good adaptation in areas with much snow (Gambaryan, 1974).

Obviously the profit with thin bones in areas with much snow is of greater value, than the increased risk to break the bones that will be the result of the reduction of the thickness.

6). But how can the foxes in the central part of Sweden have as thick bones as the Danish foxes, with the result that their weights are the same (Fig. 2)? Especially as unlike Denmark it is 100 to $300 \mathrm{~mm}$ of snow in the central part of Sweden. The reason may be that the foxes in the central part of Sweden have longer legs and larger paws than the Danish foxes (unpublished data). Therefore it has never been any need to reduce the body weight by reducing the thickness of the limbs in central Sweden. Especially as such a reduction will increase the risk to break the limbs.

7). The reason why the foxes in the most southern part of Sweden (S4) are heavier and have thicker bones than the foxes in all the other regions is that these foxes are the largest in Scandinavia (unpublished data). And with a maximum of $200 \mathrm{~mm}$ of snow during a short winter, there has never been any large advantage to reduce the body weight at least not because the snow. Since foxes in Denmark have no problem with the snow, the thickness of their bones probably is adapted to their body weight.

ACKNOWLEDGMENTS. I wish to express my appreciation to all hunters who have made this investigation possible by delivering all the foxes. I am also very grateful to Dr. M. Elmeros at the Game Biology Station at Kalø in Denmark, who supplied me with all the Danish foxes and made it possible for me to work at the Station. Furthermore I will thank the local hunter organizations in northern Sweden and the Journal for Swedish Sportsmen Association for their economic support. I am also very grateful to Professor T. Willebrand at the Hedmark University of Applied Sciences in Norway and Assistant Professor G. Samelius at the Swedish University of Agricultural Sciences (SLU) in Sweden for their economic support during several years. I am also very grateful to Dr. A. Abramov at the Zoological Institute of the Russian Academy of Sciences for the invaluable comments to the manuscript. Last but not least I will thank my wife Galina, who helped me with my work and Professor A. Bignert for statistical help and for producing the figures.

\section{References}

BignertA. 2013. The PIA application for statistical analysis of timeseries data. Available from http://www.amap.no/documents/.

Churcher Ch.S. 1960. Cranial variation in the North American red fox // Journal of Mammalogy. Vol.41. No.3. P.349-360.

Driesch A. von den 1976. A guide to the measurement of animal bones from archaeological sites // Peabody Museum Bulletin. Vol.1. P.1-136.

Englund J. 1965. Studies on food ecology of the red fox (Vulpes v.) in Sweden // Viltrevy. Vol.3. No.4. P.377-485.

Englund J. 1970. Some aspects of reproduction and mortality rates in Swedish foxes (Vulpes vulpes), 1961-1963 and 1966-1969 // Viltrevy. Vol.8. No.1. P.1-82.

Englund J. 1980. Population dynamics of the red fox (Vulpes vulpes L., 1758) in Sweden // Biogeographica. Vol.18. P.107-121.

Englund J. 2006. Cranial and skeletal size in red foxes, Vulpes vulpes (Carnivora, Canidae) in areas with large variation in food abundance // Russian Journal of Theriology. Vol.5. No.1. P.25-34.

Englund J. 2019. Anatomical response to the vole population cycles in the Swedish red foxes (Vulpes vulpes) // Russian Journal of Theriology. Vol.18. No.2. P.137-145.

Eriksson B. 1989. Snow conditions in Sweden during the seasons 1950/51-1979/80 // SMHI Report No.59. P.1-75. Norrköping.

Gambaryan P.P. 1974. How Mammals Run: Anatomical Adaptations. New York and Toronto: John Wiley \& Sons. 367 p.

Jensen B. \& Sequeira D.M. 1978. The diet of the red fox (Vulpes vulpes L.) in Denmark // Danish Review of Game Biology. Vol.10. No.8. P.1-16.

Pagh S., Tjörnlöv S.R., Olesen C.R. \& Chriel M. 2015. The diet of Danish red foxes (Vulpes vulpes) in relation to a changing agricultural ecosystem. A historical perspective // Mammal Research. Vol.60. No.4. P.319-329.

Schantz T. von. 1980. Prey consumption of a red fox population in southern Sweden // Biogeographica. Vol.18. P.53-64. 
Appendix 1. Mean body weight (kg) in adult foxes killed in winter time (all birth cohorts are lumped together).

\begin{tabular}{|c|c|c|c|c|c|c|c|c|c|c|}
\hline Sex & \multicolumn{9}{|c|}{ Males } & \multicolumn{5}{c|}{ Females } \\
\hline Region & S1 & S2 & S3 & S4 & Dk & S1 & S2 & S3 & S4 & Dk \\
\hline Mean & 6.5 & 6.9 & 7.3 & 8.8 & 7.3 & 5.4 & 5.7 & 6.1 & 7.0 & 5.8 \\
\hline sd & 1.088 & 1.125 & 1.065 & 1.282 & 0.658 & 0.911 & 0.952 & 0.832 & 0.972 & 0.512 \\
\hline$n$ & 681 & 798 & 358 & 130 & 16 & 550 & 748 & 400 & 141 & 9 \\
\hline Median & 6.4 & 6.8 & 7.2 & 8.8 & 7.4 & 5.2 & 5.7 & 6.1 & 6.9 & 5.8 \\
\hline Max & 10.4 & 12.0 & 13.5 & 14.3 & 8.4 & 9.8 & 10.0 & 8.5 & 9.8 & 6.5 \\
\hline Min & 3.5 & 3.5 & 4.5 & 5.8 & 6.0 & 3.0 & 3.2 & 3.5 & 4.1 & 4.9 \\
\hline
\end{tabular}

Appendix 2. Mean diameter (mm) in Vulpes vulpes limbs (all birth cohorts are lumped together).

\begin{tabular}{|c|c|c|c|c|c|c|c|c|c|c|c|}
\hline \multirow{8}{*}{ Humerus } & & \multicolumn{5}{|c|}{ Males } & \multicolumn{5}{|c|}{ Females } \\
\hline & Region & S1 & S2 & S3 & S4 & Dk & S1 & S2 & S3 & S4 & Dk \\
\hline & Mean & 8.21 & 8.51 & 8.65 & 9.07 & 8.64 & 7.82 & 8.03 & 8.20 & 8.55 & 8.07 \\
\hline & sd & 0.540 & 0.497 & 0.492 & 0.539 & 0.528 & 0.486 & 0.481 & 0.462 & 0.478 & 0.451 \\
\hline & $n$ & 939 & 787 & 668 & 353 & 31 & 783 & 681 & 634 & 282 & 33 \\
\hline & Median & 8.20 & 8.50 & 8.70 & 9.00 & 8.60 & 7.80 & 8.00 & 8.20 & 8.50 & 8.00 \\
\hline & Max & 10.0 & 10.1 & 9.9 & 10.8 & 9.9 & 9.4 & 10.0 & 9.6 & 9.9 & 9.2 \\
\hline & Min & 6.4 & 7.0 & 7.2 & 7.1 & 7.5 & 6.3 & 6.7 & 6.7 & 7.1 & 7.1 \\
\hline \multirow{9}{*}{ Radius } & & \multirow{2}{*}{\multicolumn{5}{|c|}{ Males }} & \multirow{2}{*}{\multicolumn{5}{|c|}{ Females }} \\
\hline & & & & & & & & & & & \\
\hline & Region & S1 & S2 & S3 & S4 & $\mathrm{Dk}$ & S1 & S2 & S3 & S4 & $\mathrm{Dk}$ \\
\hline & Mean & 8.35 & 8.57 & 8.68 & 9.27 & 8.49 & 7.85 & 8.03 & 8.15 & 8.67 & 7.96 \\
\hline & sd & 0.572 & 0.547 & 0.556 & 0.543 & 0.418 & 0.510 & 0.505 & 0.485 & 0.493 & 0.454 \\
\hline & $n$ & 1313 & 899 & 876 & 428 & 32 & 1077 & 785 & 833 & 328 & 34 \\
\hline & Median & 8.40 & 8.50 & 8.70 & 9.30 & 8.50 & 7.90 & 8.00 & 8.10 & 8.60 & 8.00 \\
\hline & Max & 10.3 & 10.2 & 10.6 & 11.1 & 9.9 & 9.4 & 9.9 & 9.5 & 10.1 & 9.0 \\
\hline & Min & 6.6 & 6.7 & 7.1 & 6.1 & 7.6 & 6.2 & 6.3 & 6.5 & 7.4 & 6.5 \\
\hline \multirow{9}{*}{ Femur } & & \multirow{2}{*}{\multicolumn{5}{|c|}{ Males }} & \multirow{2}{*}{\multicolumn{5}{|c|}{ Females }} \\
\hline & & & & & & & & & & & \\
\hline & Region & $\mathrm{S} 1$ & $\mathrm{~S} 2$ & $\mathrm{~S} 3$ & $\mathrm{~S} 4$ & Dk & $\mathrm{S} 1$ & $\mathrm{~S} 2$ & S3 & $\mathrm{S} 4$ & $\mathrm{Dk}$ \\
\hline & Mean & 9.35 & 9.64 & 9.74 & 10.25 & 9.85 & 8.95 & 9.18 & 9.33 & 9.75 & 9.25 \\
\hline & $\mathrm{sd}$ & 0.598 & 0.556 & 0.577 & 0.563 & 0.630 & 0.537 & 0.551 & 0.518 & 0.538 & 0.591 \\
\hline & $n$ & 899 & 716 & 495 & 338 & 34 & 723 & 617 & 452 & 244 & 35 \\
\hline & Median & 9.30 & 9.60 & 9.70 & 10.25 & 9.75 & 9.00 & 9.20 & 9.30 & 9.70 & 9.20 \\
\hline & Max & 11.5 & 11.6 & 11.2 & 11.6 & 11.1 & 10.5 & 11.0 & 11.1 & 11.3 & 10.7 \\
\hline & Min & 7.7 & 7.8 & 8.3 & 8.8 & 8.9 & 7.4 & 7.6 & 7.7 & 8.3 & 8.3 \\
\hline \multirow{8}{*}{ Tibia } & & \multicolumn{5}{|c|}{ Males } & \multicolumn{5}{|c|}{ Females } \\
\hline & Region & S1 & $\mathrm{S} 2$ & S3 & S4 & $\mathrm{Dk}$ & S1 & $\mathrm{S} 2$ & S3 & S4 & $\mathrm{Dk}$ \\
\hline & Mean & 8.22 & 8.46 & 8.63 & 9.22 & 8.65 & 7.81 & 8.02 & 8.17 & 8.73 & 8.18 \\
\hline & $\mathrm{sd}$ & 0.521 & 0.542 & 0.533 & 0.554 & 0.648 & 0.511 & 0.523 & 0.510 & 0.532 & 0.468 \\
\hline & $n$ & 786 & 569 & 438 & 289 & 29 & 646 & 516 & 481 & 196 & 30 \\
\hline & Median & 8.20 & 8.40 & 8.60 & 9.20 & 8.60 & 7.80 & 8.00 & 8.10 & 8.70 & 8.15 \\
\hline & Max & 9.9 & 10.2 & 10.3 & 10.4 & 10.0 & 9.4 & 9.9 & 9.7 & 10.4 & 9.4 \\
\hline & Min & 6.7 & 7.0 & 7.1 & 7.6 & 7.5 & 6.0 & 6.1 & 6.8 & 7.2 & 7.4 \\
\hline
\end{tabular}


Appendix 3. The diameter of the limbs (mm) in Vulpes vulpes born 1966 and 1967.

\begin{tabular}{|c|c|c|c|c|c|c|c|c|c|c|c|c|}
\hline \multicolumn{13}{|c|}{ Males 1966} \\
\hline Region & \multicolumn{4}{|c|}{$\mathrm{S} 1$} & \multicolumn{4}{|c|}{$\mathrm{S} 2$} & \multicolumn{4}{|c|}{ S3 } \\
\hline Bones & Humerus & Radius & Femur & Tibia & Humerus & Radius & Femur & Tibia & Humerus & Radius & Femur & Tibia \\
\hline Mean & 8.43 & 8.53 & 9.57 & 8.33 & 8.52 & 8.55 & 9.59 & 8.40 & 8.76 & 8.72 & 9.78 & 8.69 \\
\hline sd & 0.506 & 0.556 & 0.560 & 0.486 & 0.445 & 0.498 & 0.544 & 0.452 & 0.424 & 0.499 & 0.527 & 0.545 \\
\hline$n$ & 164 & 243 & 120 & 151 & 122 & 139 & 62 & 51 & 130 & 144 & 57 & 67 \\
\hline Median & 8.4 & 8.5 & 9.5 & 8.3 & 8.5 & 8.5 & 9.5 & 8.3 & 8.8 & 8.7 & 9.7 & 8.7 \\
\hline $\operatorname{Max}$ & 9.6 & 10.1 & 11.1 & 9.3 & 9.9 & 10.2 & 11.2 & 9.6 & 9.8 & 10.1 & 10.9 & 10.3 \\
\hline Min & 7.0 & 6.7 & 8.2 & 7.0 & 7.4 & 7.2 & 8.3 & 7.5 & 7.6 & 7.1 & 8.5 & 7.7 \\
\hline \multicolumn{13}{|c|}{ Males 1967} \\
\hline Region & \multicolumn{4}{|c|}{$\mathrm{S} 1$} & \multicolumn{4}{|c|}{$\mathrm{S} 2$} & \multicolumn{4}{|c|}{ S3 } \\
\hline Bones & Humerus & Radius & Femur & Tibia & Humerus & Radius & Femur & Tibia & Humerus & Radius & Femur & Tibia \\
\hline Mean & 8.00 & 8.19 & 9.20 & 8.16 & 8.42 & 8.46 & 9.53 & 8.28 & 8.57 & 8.63 & 9.76 & 8.58 \\
\hline $\mathrm{sd}$ & 0.480 & 0.563 & 0.515 & 0.533 & 0.501 & 0.553 & 0.480 & 0.511 & 0.490 & 0.578 & 0.569 & 0.556 \\
\hline$n$ & 145 & 208 & 93 & 129 & 76 & 82 & 50 & 52 & 121 & 147 & 55 & 73 \\
\hline Median & 8.0 & 8.3 & 9.2 & 8.2 & 8.4 & 8.4 & 9.4 & 8.3 & 8.6 & 8.7 & 9.8 & 8.6 \\
\hline Max & 9.1 & 10.3 & 10.5 & 9.1 & 9.6 & 10.1 & 10.6 & 9.4 & 9.8 & 9.9 & 10.9 & 10.1 \\
\hline Min & 6.8 & 6.6 & 7.8 & 6.7 & 7.4 & 7.3 & 8.7 & 7.1 & 7.3 & 7.1 & 8.3 & 7.2 \\
\hline \multicolumn{13}{|c|}{ Females 1966} \\
\hline Region & \multicolumn{4}{|c|}{ S1 } & \multicolumn{4}{|c|}{$\mathrm{S} 2$} & \multicolumn{4}{|c|}{ S3 } \\
\hline Bones & Humerus & Radius & Femur & Tibia & Humerus & Radius & Femur & Tibia & Humerus & Radius & Femur & Tibia \\
\hline Mean & 7.96 & 7.94 & 9.17 & 7.97 & 8.00 & 7.97 & 9.11 & 7.95 & 8.27 & 8.19 & 9.36 & 8.23 \\
\hline $\mathrm{sd}$ & 0.464 & 0.461 & 0.449 & 0.446 & 0.466 & 0.487 & 0.563 & 0.464 & 0.440 & 0.474 & 0.556 & 0.491 \\
\hline$n$ & 151 & 205 & 98 & 123 & 125 & 135 & 58 & 56 & 116 & 138 & 45 & 59 \\
\hline Median & 8.0 & 8.0 & 9.2 & 7.9 & 8.0 & 8.0 & 9.1 & 8.0 & 8.3 & 8.2 & 9.4 & 8.2 \\
\hline Max & 9.4 & 9.4 & 10.5 & 9.0 & 9.7 & 9.1 & 10.7 & 9.1 & 9.4 & 9.4 & 10.7 & 9.4 \\
\hline Min & 6.7 & 6.8 & 7.9 & 6.8 & 7.0 & 6.6 & 7.7 & 7.0 & 7.2 & 7.1 & 8.1 & 7.2 \\
\hline \multicolumn{13}{|c|}{ Females 1967} \\
\hline Region & \multicolumn{4}{|c|}{$\mathrm{S} 1$} & \multicolumn{4}{|c|}{ S2 } & \multicolumn{4}{|c|}{ S3 } \\
\hline Bones & Humerus & Radius & Femur & Tibia & Humerus & Radius & Femur & Tibia & Humerus & Radius & Femur & Tibia \\
\hline Mean & 7.66 & 7.73 & 8.84 & 7.71 & 7.86 & 7.92 & 9.08 & 7.88 & 8.11 & 8.10 & 9.26 & 8.06 \\
\hline $\mathrm{sd}$ & 0.465 & 0.451 & 0.530 & 0.469 & 0.506 & 0.484 & 0.646 & 0.494 & 0.458 & 0.539 & 0.577 & 0.502 \\
\hline$n$ & 124 & 170 & 85 & 106 & 79 & 91 & 40 & 45 & 109 & 135 & 56 & 85 \\
\hline Median & 7.7 & 7.7 & 8.8 & 7.7 & 7.9 & 8.0 & 9.1 & 7.9 & 8.2 & 8.1 & 9.3 & 8.1 \\
\hline $\operatorname{Max}$ & 9.1 & 9.0 & 10.2 & 8.7 & 9.2 & 9.1 & 10.4 & 9.2 & 9.2 & 9.5 & 10.9 & 9.2 \\
\hline Min & 6.8 & 6.6 & 7.8 & 6.6 & 6.7 & 6.8 & 7.6 & 6.7 & 6.7 & 6.5 & 7.8 & 6.8 \\
\hline
\end{tabular}

